\title{
KARAKTERISASI ISOLAT BAKTERI FIBRINOLITIK WU 021055* ASAL PERAIRAN PANTAI PAPUMA, JEMBER
}

\section{Characterization of Fibrinolytic Bacteria WU 021055* from Papuma Coast, Jember}

\author{
Ajeng Maharani Sri Pananjung ${ }^{1}$, Evi Umayah Ulfa ${ }^{1}$, Kartika Senjarini $^{2, *}$, Sattya Arimurti $^{2}$ \\ ${ }^{1}$ Fakultas Farmasi, Universitas Jember \\ ${ }^{2}$ Fakultas Matematika dan IImu Pengetahuan Alam, Universitas Jember, Jln. Kalimantan 37, Jember 68121 \\ *E-mail: senjarini@unej.ac.id
}

\begin{abstract}
A blood clot (thrombus) in a blood stream is formed due to a circulatory system imbalance in the hemostasis which results in plug of blood vessels. The suppliy of nutrients and oxygen to the tissues is inhibited (ischemia) by the accumulation of thrombus and embolus in the blood vessel. This prosses is the main cause for further atherotrombotic diseases such as myocardial infraction and cerebral infraction. This disease could be overcome by thrombolytic therapy by using fibrinolytic protease enzyme. Fibrinolytic activity of protease enzymes have been studied from various species of bacteria. Bacterial isolate of WU 021055* obtained from Papuma coastal waters has demonstrated fibrinolytic activity. This research was aimed to identify the bacterial isolate through morphological characterization (colony and cell morphology), physiological characterization (indole test, carbohydrates fermentation test (glucose, lactose, sucrose and fructose), catalase test, starch hydrolysis test, and the $\mathrm{pH}$ effect test), and molecular identification using 16S rRNA. Based on those characterizations, the bacterial isolate of WU $021055^{\star}$ shows a high similarity to Bacillus aerius.
\end{abstract}

Keywords: Atherotrombosis, fibrinolytic, identification, characterization, bacteria

\begin{abstract}
ABSTRAK
Bekuan darah (trombus) dalam peredaran darah terbentuk akibat ketidakseimbangan sistem sirkulasi dalam hemostasis yang menyebabkan penyumbatan pembuluh darah. Akumulasi trombus dan embolus pada pembuluh darah mengakibatkan suplai nutrisi dan oksigen ke jaringan terhambat (iskemia) dan bahkan kematian jaringan (infark). Pembentukan ini merupakan etiologi dari penyakit aterotrombosis seperti infark miokard dan infark serebral. Penyakit akibat trombosis ini dapat diatasi dengan terapi trombolitik dengan enzim protease fibrinolitik. Aktivitas enzim protease fibrinolitik telah diteliti dari berbagai spesies bakteri. Isolat bakteri WU $021055^{*}$ asal perairan pantai papuma tampak memiliki aktivitas fibrinolitik. Pada penelitian ini dilakukan identifikasi isolat bakteri melalui karakterisasi morfologi (morfologi koloni dan sel), karakterisasi fisiologis (uji indol, uji fermentasi karbohidrat (glukosa, laktosa, sukrosa dan fruktosa), uji katalase, uji hidrolisis pati, dan uji pengaruh $\mathrm{pH}$ ), dan identifikasi secara molekuler menggunakan 16S rRNA. Berdasarkan karakterisasi morfologi, fisiologi, dan marker 16S rRNA, isolat bakteri WU 021055* menunjukkan kemiripan yang tinggi dengan Bacillus aerius.
\end{abstract}

Kata kunci: Aterotrombosis, fibrinolitik, identifikasi, karakterisasi, bakteri 


\section{PENDAHULUAN}

Penyakit atherotrombosis seperti infark miokard dan infark serebral merupakan penyakit yang terjadi akibat sumbatan bekuan darah (trombus) pada pembuluh darah (arteri). Pada tahun 2004, penyakit tersebut merupakan penyebab kematian utama di dunia. Terhitung sebanyak $7.200 .000(12,2 \%)$ kematian terjadi akibat penyakit ini di seluruh dunia (World Health Organization 2008). Salah satu penyebab dari infark miokard dan infark serebral adalah trombosis yang diakibatkan oleh ruptur dari plak aterosklerosis pada dinding pembuluh darah sehingga menghasilkan bekuan darah. Bekuan darah terbentuk disebabkan karena sistem sirkulasi yang tidak seimbang dalam hemostasis sehingga terjadi penyumbatan pembuluh darah. Derajat sumbatan bekuan darah dan ukuran infark ditentukan oleh derajat dan lokasi proses pembentukan bekuan darah (Prasad et al. 2007).

Trombus yang menyumbat pembuluh darah tersebut dapat dihancurkan dengan mekanisme trombolisis (fibrinolisis). Fibrinolisis bekerja dengan mengaktifkan plasminogen menjadi enzim proteolitik plasmin. Plasmin akan mengubah bentuk trombus dan membatasi perkembangan trombosis dengan mencerna proteolitik fibrin (Kumada et al. 1994). Mekanisme kerja enzim fibrinolitik adalah dengan menghidrolisis fibrin yang menyebabkan bekuan darah menjadi produk terlarut yang dapat dibuang dari peredaran darah sehingga membebaskan pembuluh darah dari bekuan darah dan memulai proses penyembuhan dinding pembuluh darah (Escobar et al. 2002). Agen fibrinolitik dapat diperoleh dari tanaman, hewan, atau mikroba. Penggunaan mikroba khususnya bakteri telah banyak diteliti sebagai penghasil agen fibrinolitik.

Indonesia merupakan negara yang memiliki wilayah perairan laut yang sangat luas, sekitar dua pertiga wilayah negara ini berupa lautan. Review riset mengenai diversitas biota laut dari perairan Indonesia mengindikasikan bahwa potensi biota laut Indonesia sebagai penghasil senyawa bioaktif dalam pengembangan obat sangat besar (Chasanah 2009). Hasil penelitian Setiawan (2013), menunjukkan bahwa bakteri asal perairan pantai Papuma yaitu isolat dengan kode WU 021055* memiliki aktifitas fibrinolitik. Isolat telah diuji aktivitas fibrinolitiknya menggunakan metode fibrin plate assay dengan indeks aktivitas enzim fibrinolitik sebesar 11. Karena potensi yang dimiliki isolat bakteri tersebut sebagai penghasil enzim fibrinolitik maka karakterisasi terhadap bakteri tersebut sangatlah penting. Salah satu karakterisasi yang dapat dilakukan yaitu identifikasi isolat bakteri. Identifikasi isolat bakteri dapat dilakukan dengan metode konvensional dan metode molekuler. Metode konvensional didasarkan pada identifikasi fenotip diantaranya pemeriksaan morfologi, fisika, kimia, biokimia. Identifikasi mikroorganisme secara molekuler menggunakan penanda molekul tertentu, seperti 16S rRNA atau gen pengkodenya. Metode molekuler ini didasarkan pada teknik polymerase chain reaction (PCR) yang merupakan teknik penggandaan in vitro. Sekuen 16S rRNA juga digunakan sebagai penanda molekuler karena molekulnya bersifat ubiquitous (terdapat di semua makhluk hidup) dengan fungsi yang identik pada seluruh organisme. Penggunaan molekul 16S rRNA menjadi pilihan yang banyak digunakan untuk melacak filogeni bakteri. Selain itu informasi genetik dari sekuen 16S rRNA cukup lengkap pada data base Gene Bank sehingga lebih mudah untuk melihat kekerabatan bakteri.

\section{BAHAN DAN METODE}

Bahan yang digunakan adalah satu isolat bakteri dari Perairan Pantai Papuma Jember koleksi Laboratorium Mikrobiologi Jurusan Biologi, Fakultas Matematika dan IImu Pengetahuan Alam, Universitas Jember yang memiliki aktivitas fibrinolitik yaitu WU 0210155*. Alat yang digunakan adalah mikroskop elektron Olympus BX53F dan mesin polymerase chain reaction (PCR) Techne TC-312.

\section{Peremajaan isolat bakteri}

Isolat bakteri dalam stok gliserol $\left(-80^{\circ} \mathrm{C}\right)$ diremajakan dengan cara bakteri ditumbuhkan pada media NB (Nutrient Broth) cair dan digoyangkan pada suhu ruang selama 18 jam. Hasil peremajaan dimurnikan koloninya untuk mendapatkan koloni tunggal (single colony) dengan cara streak pada media NB padat dan diinkubasi pada inkubator dengan suhu ruang 
selama 48 jam. Koloni tunggal hasil peremajaan dibiakkan kembali dalam media NB cair selama 18 jam.

\section{Pewarnaan gram isolat bakteri}

Pewarnaan Gram dilakukan dengan membuat usapan tipis suspensi dari isolat bakteri berumur 24 jam pada gelas objek yang bersih, kemudian dikeringanginkan. Setelah kering, difiksasi dengan cara melewatkan bagian bawah gelas objek di atas api bunsen. Selanjutnya hapusan bakteri ditetesi dengan larutan Kristal violet selama 1 menit. Dibilas dengan air kran mengalir. Kemudian ditetesi dengan larutan iodine dan dibiarkan selama 1 menit. Dibilas dengan air kran mengalir. Dibilas dengan alkohol 96\% selama 20 detik. Dibilas kembali dengan air kran mengalir. Ditetesi dengan safranin selama 45 detik. Terakhir dibilas dengan air kran mengalir, dan diletakkan di atas kertas serap. Hasil pewarnaan Gram isolat bakteri diamati di bawah mikroskop dengan pembesaran 1000x. Untuk memperjelas morfologi sel, cover glass di atas suspensi bakteri ditetesi dengan minyak imersi dan perhitungan koloni bakteri dengan menggunakan koloni counter. Sel bakteri Gram positif akan berwarna ungu hingga biru, sedangkan bakteri Gram negatif akan berwarna merah.

\section{Karakterisasi biokimia}

Karakterisasi isolat bakteri WU 021055* yang dilakukan meliputi uji indol, uji fermentasi karbohidrat (glukosa, laktosa, sucrosa dan fruktosa), uji katalase, uji hidrolisis pati, dan uji pengaruh $\mathrm{pH}$. Uji indol dilakukan dengan inokulasi isolat bakteri ke dalam medium NB padat pada tabung reaksi secara aseptik, di inkubasi pada suhu $37^{\circ} \mathrm{C}$ selama 24 jam, kemudian ditetesi dengan reagen Kovac's. Uji fermentasi karbohidrat (glukosa, laktosa, sucrosa dan fruktosa) dilakukan dengan menambahkan medium NB cair dengan brom tymol blue (BTB) sebagai indikator dimasukkan ke dalam tabung reaksi, ditambahkan gula yang di fermentasikan $1-2 \%$. Isolat diinokulasi dan diinkubasi pada suhu $37^{\circ} \mathrm{C}$ selama 24 jam (Cappuccino dan Sherman 1987).

Uji katalase dilakukan dengan cara isolat diberi 2 tetes reagen hidrogen peroksida $\left(\mathrm{H}_{2} \mathrm{O}_{2}\right) 3 \%$. Pada uji hidrolisis pati, isolat bakteri digoreskan pada media pati dan diinkubasi selama 24 jam. Permukaan koloni ditetesi dengan iodin. Uji pengaruh $\mathrm{pH}$ dilakukan dengan menumbuhkan satu ose isolat bakteri dari suspensi biakan dalam larutan media NB cair dibuat dalam suasana $\mathrm{pH}$ yang berbeda yaitu $\mathrm{pH} 3,5,7$ dan diinkubasi selama 24 jam.

\section{Isolasi DNA kromosom isolat bakteri}

Kultur bakteri sebanyak $1000 \mu \mathrm{l}$ disentrifugasi $13.000 \times \mathrm{g}$ selama 5 menit pada suhu $4^{\circ} \mathrm{C}$ sehingga didapatkan pelet dan diulang sebanyak tiga kali. Isolasi DNA dilakukan mengikuti prosedur Wizard® Genomic DNA Purification Kit.

\section{PCR DNA pengkode 16S rRNA}

Isolat bakteri yang terlihat pita DNA genomnya diamplifikasi dengan menggunakan primer DNA pengkode 16S rRNA yaitu 27F (5' AGA GTT TGA TCM TGG CTC AG 3'), 533F (5' GTG CCA GCM GCC GCG GTA A 3') dan 907R (5' CCG TCA ATT CMT TTG AGT TT 3'), 1492R (5' GGT TAC CTT GTT ACG ACT T 3') (Lane,1991). PCR dilakukan dengan mereaksikan $15 \mu \mathrm{l}$ aquabidest steril, $25 \mu \mathrm{l} 2 x$ PCR Master mix

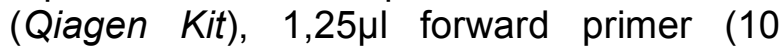
$\mathrm{pmol} / \mu \mathrm{l}$, konsentrasi akhir $0,25 \mathrm{pmol} / \mu \mathrm{l})$, $1,25 \mu \mathrm{l}$ reverse primer $(10 \mathrm{pmol} / \mu \mathrm{l}$, konsentrasi akhir $0,25 \mathrm{pmol} / \mu \mathrm{l})$ dan $2 \mu \mathrm{l}$ ekstrak DNA. Suhu denaturasi $98^{\circ} \mathrm{C}$ dalam 5 menit dan $95^{\circ} \mathrm{C}$ dalam 35 detik; annealing dengan suhu $55^{\circ} \mathrm{C}$ selama 35 detik dan elongasi pada suhu $72^{\circ} \mathrm{C}$ dalam 90 detik. Total siklus 35 kali.

\section{Purifikasi DNA hasil PCR}

Purifikasi hasil PCR dilakukan melalui pemotongan gel agarosa yang mengandung pita DNA hasil PCR. Produk PCR dimurnikan pada $1 \%$ gel agarosa mengikuti prosedur PCR clean-up Gel Extraction Nucleospin $®$ Extract II. Produk purifikasi DNA hasil PCR diukur dengan menggunakan NanoDrop spektrofotometer.

\section{Analisis data sekuen DNA}

Penentuan urutan DNA murni (sequencing) dilakukan dengan mengirimkan DNA hasil purifikasi dari produk PCR ke $1^{\text {st }}$ BASE Singapura. Bioedit software (Tom Hall, Ibis Theraupetics) digunakan untuk analisis data kasar hasil sequencing. Setelah 
Tabel 1. Hasil Pengamatan Morfologi Isolat Bakteri WU 021055*

\begin{tabular}{lc}
\hline Karakteristik & Hasil \\
\hline Bentuk Koloni & Bulat \\
Bentuk Tepian Koloni & Bergerigi \\
Warna koloni & Putih \\
Bentuk Sel & Basil \\
Warna Sel & Ungu \\
Gram (+/-) & + \\
\hline
\end{tabular}

diketahui alignment sekuen DNA pengkode 16S rRNA dari masing-masing isolat maka sekuen dibandingkan dengan database gen pengkode $16 \mathrm{~S}$ rRNA menggunakan BLAST online software (www.ncbi.nlm.nih.gov.) untuk menentukan spesies dari isolat dan hubungan kekerabatan dengan spesies bakteri lainnya

\section{HASIL DAN PEMBAHASAN}

Identifikasi secara fenotip dilakukan sebagai tahap awal sebelum identifikasi lebih lanjut. Identifikasi fenotip meliputi morfologi isolat bakteri yaitu, bentuk koloni, bentuk tepian koloni, warna koloni dan juga morfologi sel isolat bakteri pada (Tabel 1). Koloni isolat bakteri merupakan sekumpulan dari masa sel yang dapat dilihat secara langsung dengan mata. Semua sel dalam koloni itu sama dan dianggap semua sel tersebut merupakan keturunan (progeny) dari satu mikroorganisme dan mewakili sebagai biakan murni. Penampakan koloni isolat bakteri WU 021055* berbentuk bulat, tepi bergerigi dan berwarna putih. Semua koloni dalam media tumbuh menunjukkan warna dan bentuk koloni yang homogen sehingga dapat disimpulkan bahwa isolat bakteri WU 021055* pada (Gambar 1) dalam media tumbuh tersebut murni.

Pengamatan pewarnaan Gram menunjukkan isolat bakteri WU 021055* bersifat Gram positif dengan bentuk sel basil yang dibandingkan dengan kontrol negatif $E$. coli dan kontrol positif $B$. subtilis. Menurut Jawetz et al (2008) bakteri dibagi dalam golongan Gram positif dan Gram negatif berdasarkan reaksinya terhadap pewarnaan Gram. Bakteri dikatakan Gram negatif apabila sel bakteri berwarna merah dan termasuk Gram positif apabila sel bakteri berwarna ungu. Hasil pewarnaan isolat bakteri WU 021055* pada Gambar 2 menunjukkan Gram positif dan berbentuk basil. Disimpulkan bahwa isolat bakteri WU 021055* termasuk dalam Genus Bacillus.

Karakterisasi fisiologis isolat bakteri WU 021055* diamati berdasarkan pengamatan uji biokimia. Hasil uji biokimia isolat bakteri WU 021055* menunjukkan hasil positif pada pengujian hidrolisis pati yang ditandai dengan perubahan warna pada media uji. Uji katalase positif ditandai dengan adanya gelembung pada media uji. Isolat bakteri WU 021055* dapat tumbuh optimal pada $\mathrm{pH}$ 7. Hal ini ditandai dengan keruhnya media uji pada kondisi $\mathrm{pH}$ 7. Pada pengujian fermentasi karbohidrat menunjukkan hasil negatif ditandai dengan tidak terbentuknya gelembung pada tabung durham. Uji pembentukan indol memberikan hasil negatif ditandai dengan tidak terbentuknya cincin merah pada media uji.

Teori dari identifikasi bakteri dengan teknik konvensional adalah membandingkan bakteri yang sedang diidentifikasi dengan bakteri yang telah teridentifikasi sebelumnya. Bila tidak terdapat bakteri yang ciri-cirinya $100 \%$ serupa, maka dilakukan pendekatan terhadap bakteri yang memiliki ciri-ciri yang paling menyerupai. Oleh karena itu teknik identifikasi dengan metode konvensional akan selalu menghasilkan suatu bakteri tertentu yang sudah teridentifikasi sebelumnya dan tidak akan dapat menemukan spesies baru (Cowan 1974). Menurut Claus dan Barkeley (1986) genus Bacillus mempunyai sifat fisiologis yang menarik karena tiap-tiap jenis mempunyai kemampuan yang berbeda-beda. Genus Bacillus ditemui di berbagai lingkungan termasuk udara, tanah, perairan, dan makanan fermentasi. Sravankumar et al. (2010) juga mengemukakan bahwa bakteri

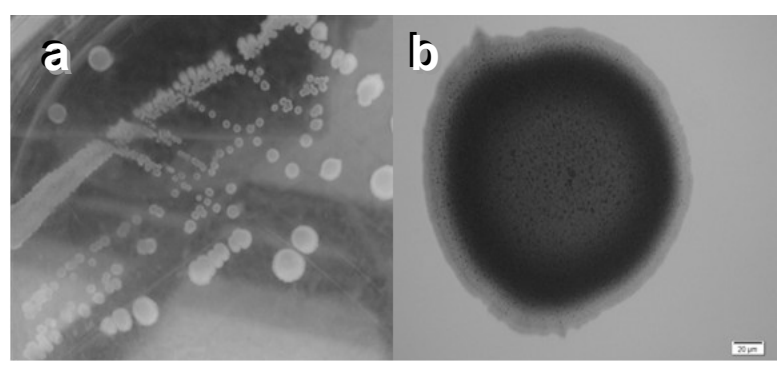

Gambar 1. (a) Morfologi koloni isolat bakteri WU 021055* pada cawan petri dan (b) Morfologi satu koloni isolat bakteri WU $021055^{*}$ pada pembesaran $1000 \mathrm{x}$. 
$B$. aerius memiliki bentuk basil, gram positif, dan hasil uji biokimia (Tabel 2). Hasil karakterisasi fisiologis menunjukkan kesamaan isolat bakteri WU 021055* dengan $B$. aerius yang diteliti sebelumnya.

Pada penelitian Setiawan (2013) isolat bakteri WU 021055* menunjukkan aktivitas fibrinolitik ditandai dengan terbentuknya zona bening di sekitar koloni bakteri yang diuji pada media fibrin agar. Enzim fibrinolitik merupakan kelompok enzim protease yang mampu mendegradasi fibrin atau fibrinogen. Enzim fibrinolitik dapat diaplikasikan pada penderita trombosis karena enzim ini dapat menghancurkan fibrin dalam bekuan darah menjadi produk degradasinya yang lebih larut dalam darah (Sajuthi et al. 2010). Dilaporkan dalam penelitian Zhang et al (2012), bahwa B. aerius memiliki protein dengan aktivitas trombolitik, antikoagulan, dan hemolisis. Hal ini menunjukkan bahwa isolat bakteri WU 021055* memiliki kesamaan aktivitas fibrinolitik dengan $B$. aerius.

Karakterisasi secara molekuler menggunakan sekuen 16S rRNA sebagai kunci identifikasi. Analisis 16S rRNA

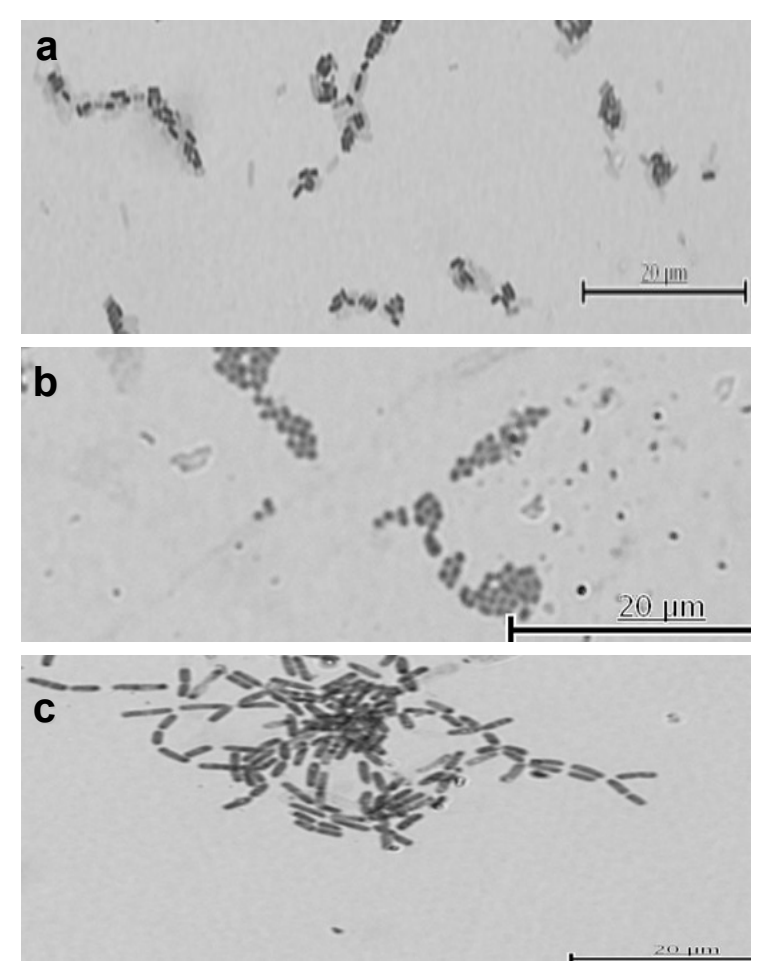

Gambar 2. Hasil pewarnaan Gram (a) Isolat Bakteri WU 021055*(+); (b) Kontrol (-) E.coli; (c) Kontrol (+) B. Subtilis. Pewarnaan Gram dengan umur kultur 24-48 jam pada pembesaran $1000 \mathrm{x}$
Tabel 2. Hasil Uji Biokimia Isolat Bakteri WU 021055*

\begin{tabular}{lcc}
\hline Pengujian & $\begin{array}{c}\text { Karakteristik } \\
\text { B. aerius } \\
\text { (Sravankumar 2010) }\end{array}$ & $\begin{array}{c}\text { Hasil (+/-) } \\
\text { pengamatan }\end{array}$ \\
\hline Hidrolisis pati & + & + \\
Katalase & + & + \\
Fermentasi karbohidrat:: & - & - \\
a. sukrosa & - & - \\
b. fruktosa & - & - \\
c. glukosa & - & - \\
d. laktosa & & - \\
Pengaruh pH: & & - \\
a. pH 3 & & + \\
b. pH 5 & & + \\
c. pH 7 & & - \\
d. $\mathrm{pH} 9$ & & \\
Pembentukan indol & - &
\end{tabular}

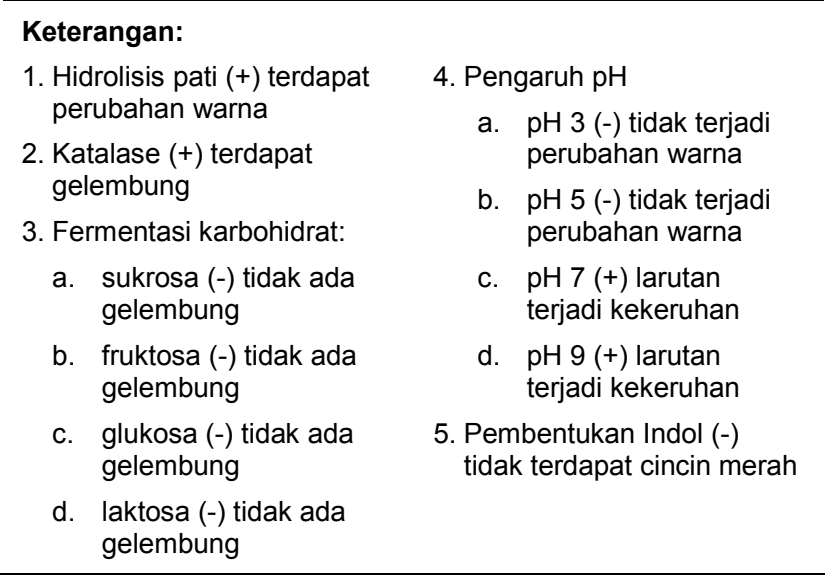

menggunakan prinsip PCR yaitu melibatkan beberapa siklus yang masing-masing terdiri dari tiga tahap berurutan, yaitu pemisahan (denaturasi) rantai cetakan DNA, penempelan (annealing) pasangan primer pada DNA target dan pemanjangan (elongasi) primer atau reaksi polimerisasi yang dikatalisis oleh DNA polimerase. Dalam proses PCR diperlukan DNA kromosom sebagai template yaitu sebagai cetakan untuk pembentukan molekul DNA baru melalui isolasi DNA kromosom.

Hasil isolasi DNA kromosom pada Gambar 3 menunjukkan adanya satu pita di atas 10.000 bp jika dibandingkan dengan marker $1 \mathrm{~kb}$. Pada umumnya ukuran DNA kromosom bakteri berukuran lebih dari 10.000 bp. Ukuran DNA kromosom yang tidak dapat ditentukan, namun ukuran tersebut dapat diindikasikan bahwa pita DNA tersebut merupakan DNA kromosom bakteri dan bukan merupakan plasmid atau DNA organel. DNA organel misalnya DNA mitokondria atau DNA 
Tabel 3. Beberapa organisme yang memiliki kemiripan terdekat dengan isolat bakteri WU $021055^{\star}$ berdasarkan urutan nuklotida DNA pengkode 16S rRNAnya.

\begin{tabular}{|c|c|c|c|c|c|}
\hline Description & $\begin{array}{l}\text { Max } \\
\text { score }\end{array}$ & $\begin{array}{l}\text { Total } \\
\text { score }\end{array}$ & $\begin{array}{l}\text { Query } \\
\text { cover }\end{array}$ & $\begin{array}{c}E \\
\text { value }\end{array}$ & Ident \\
\hline Bacillus aerius strain $24 \mathrm{~K} 16 \mathrm{~S}$ ribosomal RNA gene, partial sequence & 1482 & 1482 & $100 \%$ & 0.0 & $99 \%$ \\
\hline Bacillus stratosphericus strain 41KF2a $16 \mathrm{~S}$ ribosomal RNA gene, partial sequence & 1482 & 1482 & $100 \%$ & 0.0 & $99 \%$ \\
\hline Bacillus altitudinis strain 41KF2b $16 \mathrm{~S}$ ribosomal RNA gene, partial sequence & 1482 & 1482 & $100 \%$ & 0.0 & $99 \%$ \\
\hline Bacillus stratosphericus strain 41KF2a 16S ribosomal RNAgene, partial sequence & 1478 & 1478 & $99 \%$ & 0.0 & $99 \%$ \\
\hline Bacillus safensis strain NBRC 10082016 S ribosomal RNAgene, partial sequence & 1459 & 1459 & $100 \%$ & 0.0 & $98 \%$ \\
\hline Bacillus pumilus strain NBRC $1209216 S$ ribosomal RNA gene, partial sequence & 1459 & 1459 & $100 \%$ & 0.0 & $98 \%$ \\
\hline
\end{tabular}

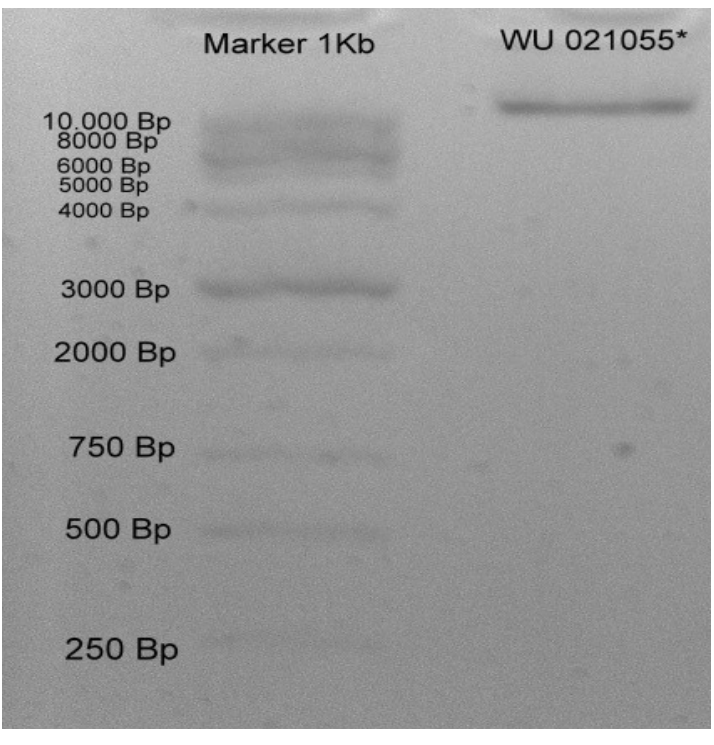

Gambar 3. Elektroforegram hasil isolasi DNA kromosom isolat bakteri asal perairan pantai Papuma, Jember.

kloroplas tidak terdapat dalam sel bakteri karena sel bakteri tidak memiliki organel tersebut sehingga dapat dipastikan DNA tersebut adalah DNA kromosom.

Amplifikasi dengan PCR 16S rRNA dilakukan menggunakan primer universal yang dapat mengamplifikasi keseluruhan gen pada bakteri berdasarkan daerah konservatif dari gen pengkode $16 \mathrm{~S}$ rRNA. Hasil amplifikasi DNA pengkode 16S rRNA menunjukkan bahwa pita DNA hasil PCR dengan pasangan primer yang pertama $27 \mathrm{~F}$ dan 907R tampak sejajar dengan pita DNA marker yang berukuran 900 bp. Hal ini relevan dengan hasil yang diharapkan yaitu fragmen DNA berukuran 873 bp yang berkisar di pita DNA marker tersebut. Pita DNA hasil PCR dengan pasangan primer yang kedua yaitu $533 \mathrm{~F}$ dan $1492 \mathrm{R}$ berada pada kisaran fragmen marker yang

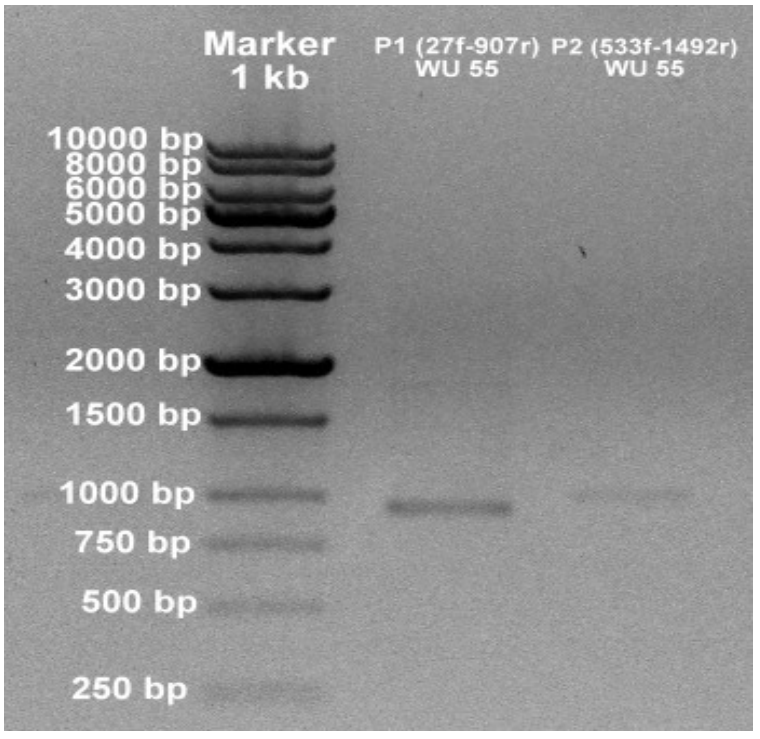

Gambar 4. Elektroforegram hasil pemurnian produk PCR DNA pengkode $16 S$ rRNA isolat WU 021055* melalui elektroforesis gel agarosa.

berukuran 1000 bp. Hasil ini sesuai dengan ekspektasi ukuran hasil PCR menggunakan primer tersebut yaitu $959 \mathrm{bp}$.

Selanjutnya, untuk mendapatkan produk PCR yang murni dan tidak terkontaminasi oleh sisa-sisa PCR perlu dilakukan pemurnian produk PCR. Pemurnian ini penting dilakukan agar proses sequencing DNA berlangsung dengan baik dan mendapatkan kualitas yang baik pula. DNA sampel yang memiliki kualitas kemurnian yang baik yaitu memiliki nilai 1,72,0 dari perbandingan A260/A280 (Oswald 2007). Nilai pengukuran kemurnian hasil purifikasi produk PCR termasuk dalam rentang murni yaitu antara 1,7-2,0. Konsentrasi sampel DNA dapat dihitung dengan membandingkan intensitas pita DNA sampel dengan konsentrasi masing-masing pita DNA marker (Oswald 2007). Hasil PCR 
Amplifikasi DNA pengkode 16S rRNA yang telah dimurnikan dan diukur konsentrasinya melalui NanoDrop Spektro-fotometri dapat dilihat pada Gambar 4.

Hasil amplifikasi PCR gen 16S rRNA yaitu 873 bp pada pasangan primer yang pertama 27F dan 907R serta pasangan primer yang kedua $533 \mathrm{~F}$ dan $1492 \mathrm{R}$ yaitu 959 bp kemudian dilakukan sequencing. Proses sekuensing dilakukan dengan menggunakan jasa $1^{\text {st }}$ BASE. Hasil pembacaan fragmen DNA berupa untai tunggal. Pada penelitian ini data sequencing yang diperoleh berupa sekuen utuh DNA pengkode 16S rRNA isolat WU 021055* yang telah diolah secara manual menggunakan software BioEdit menjadi input program BLAST. Hasil sekuen utuh 16S rRNA pada penelitian didapatkan 835 bp, panjang urutan basa nukleotida tersebut cukup mampu mengidentifikasi isolat hingga tingkat genus dan pembacaan tingkat spesies dalam gen pengkode $16 \mathrm{~S}$ rRNA untuk mengidentifikasi isolat bakteri. Hasil analisis sekuen DNA pengkode 16S rRNA menunjukkan blast sekuen WU 021055* dengan data 16S rRNA di Gene Bank. Beberapa organisme yang memiliki homologi tertinggi (99\%) dengan isolat bakteri WU $021055^{*}$ dapat dilihat pada (Tabel 3).

Menurut Drancourt (2000) berdasarkan data urutan gen pengkode 16S rRNA, homologi dengan nilai $\geq 99 \%$ menunjukkan bahwa spesies yang dibandingkan merupakan spesies yang sama, sedangkan homologi dengan nilai $\geq 97 \%$ dinyatakan bahwa isolat yang dibandingkan berada pada genus yang sama dan homologi antara $89-93 \%$ menunjukkan famili yang berbeda. Tetapi hal ini perlu ditelusuri melalui analisis filogenetik dengan melihat percabangan yang dibentuk oleh isolat melalui pengamatan posisi yang ditempati diantara spesies yang lain atau spesies pembandingnya. Pohon filogeni pada Gambar 5 menunjukkan bahwa isolat WU 021055* terletak sejajar dengan $B$. aerius yang berarti bahwa isolat WU 021055* merupakan $B$. aerius.
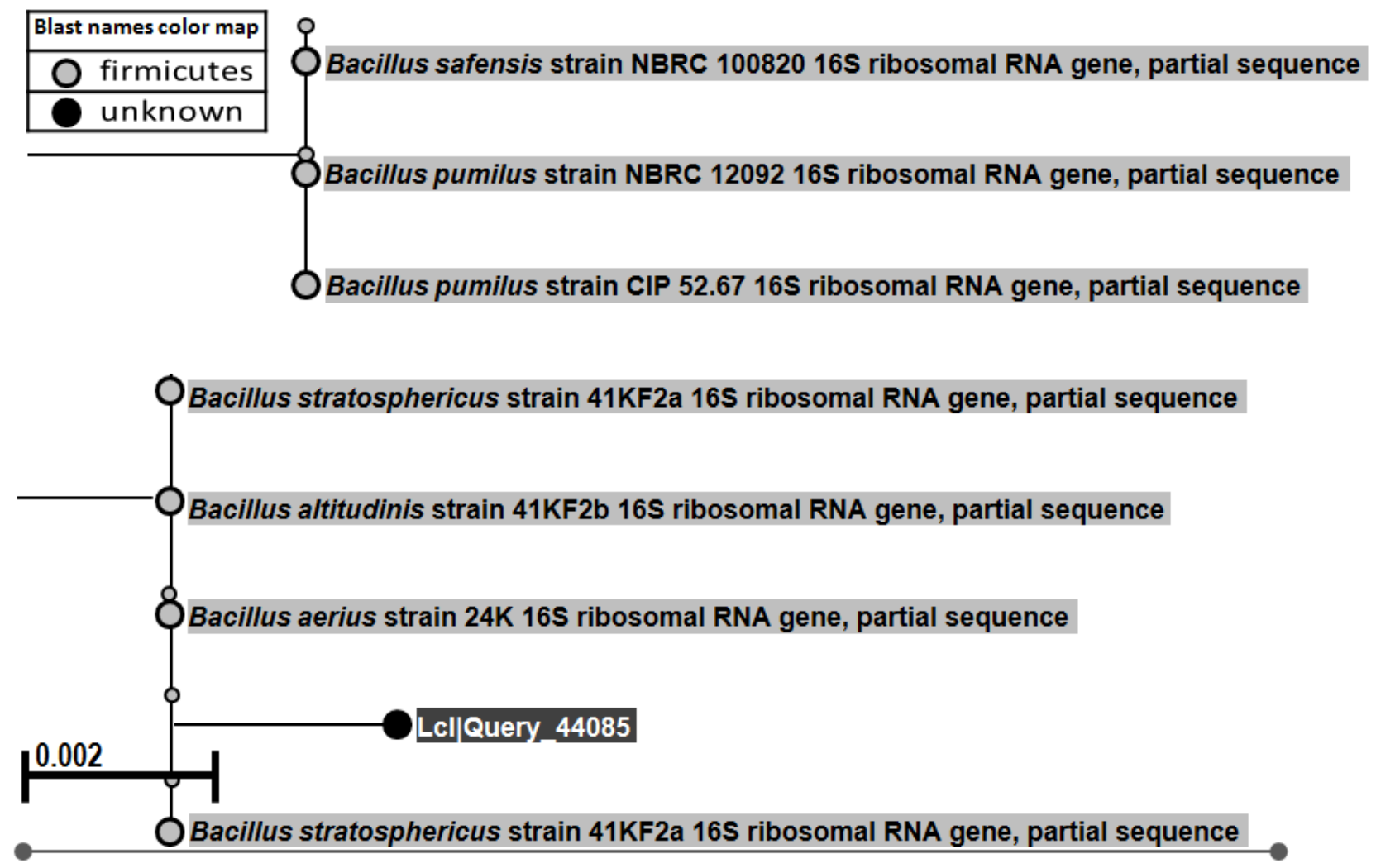

Gambar 5. Pohon filogeni yang menunjukkan hubungan kedekatan isolat WU $021055^{\star}$ dengan bakteri yang terdapat di Gene Bank 


\section{KESIMPULAN}

Berdasarkan hasil analisis dan pembahasan, maka dapat diambil kesimpulan bahwa hasil pemeriksaan morfologi bakteri dan uji biokimia menujukkan bahwa isolat bakteri WU 021055* memiliki ciri yang sama dengan Bacillus aerius. Berdasarkan hasil analisis sekuen dengan menggunakan program BLAST pada sekuen utuh hasil editing produk sequencing DNA pengkode 16S rRNA, isolat bakteri WU 021055* merupakan Bacillus aerius dengan presentase kemiripan $99 \%$.

\section{UCAPAN TERIMA KASIH}

Terima kasih diucapkan kepada DIPA Universitas Jember yang telah membiayai penelitian ini melalui program Fundamental Nasional 2014 DIKTI.

\section{DAFTAR PUSTAKA}

Cappucino JG, Sherman N (1987) Microbiology, A Laboratory Manual. California. Menko Park The Benjamin/ Cummins Publishing Company, Menlo Park, California

Chasanah E (2009) Marine biodiscovery research In Indonesia: challenges and rewards. J Coastal Dev 12:1-12

Claus D, Berkeley CW (1984) EndosporeForming Rods and Cocci. Dalam: NR Krieg \& JG Jolt (ed.), Bergeys Manual of Determinative Bacteriology. Williams and Wilkins, Baltimore: 529-551

Cowan ST (1974) Manual for the Identification of Medical Bacteria. Cambridge University Press, London

Drancourt M, Bollet C, Carlioz A, Martelin R, Gayral JP, Raoult D (2000) 16S ribosomal DNA sequence analysis of a large collection of environmental and clinical unidentifiable bacterial isolates. J Clin Microbiol 38:3623-3630

Escobar CE, Harmaening DM, Simmons VL, Smith, Moore KM, Wyrick-Glatzel J (2002) Introduction to Hemostasis. Dalam: DM Harmening (ed.), Clinical Hematology and Fundamentals of Hemostasis. (Edisi Keempat) FA Davis, Philadelphia
Jawetz M, Adelberg (2008) Mikrobiologi Kedokteran. Alih Bahasa oleh Huriwati Hartanto. Penerbit Buku Kedokteran ECG, Jakarta

Lane DJ, Pace B, Olsen GJ, Stahl DA, Sogin ML, Pace NR (1985) Rapid determination of $16 \mathrm{~S}$ ribosomal RNA sequences for phylogenetic analyses. Proc Natl Acad Sci USA 82:69556959

Sravankumar G, Durgaprasad YVK, Ramana T, Hasasreeramulu, Devi CSLV (2010) Isolation and identification of bacteria from marine biofilm on the artificial plat forms (iron panels) from Visakhapatham coast, India. Indian J Mar Sci 43:955-959

Kumada K, Onga T, Hoshino H (1994) The effect of natto possessing a high fibrinolytic activity in human plasma. Igaku to Seibutsugaku 128:117-119

Oswald N (2007) Quick reference: Determining DNA Concentration and Purity. [online] http://bitesizebio.com/13501/ dna-concentration-purity/ diakses 17 Desember 2015

Prasad S, Kashyap RS, Deopujari JY, Purohit HJ, Taori GM, Daginawala HF (2007) Effect of Fagonia Arabica (Dhamasa) on in vitro Thrombolysis. BMC Complem Altern Med 7:36

Setiawan A (2013) Skrining Agen Fibrinolitik Isolat Bakteri dari Perairan pantai papuma kabupaten jember. Skripsi fakultas kesehatan masyarakat Universitas Jember

Sajuthi, Suparto, Yanti, Praira (2010) Purifikasi dan Pencirian Enzim Protease Fibrinolitik dari Ekstrak Jamur Merang. Makara Sains 14:145-150

World Health Organization (2008) The World Health Report 2008: Primary Health Care Now More Than Ever. Geneva: WHO Library Cataloguing-inPublication

Xin ZXYHX, Baocheng Z (2012) Enzymological Properties and Thrombolysis Effect in Vitro of Fibrinolytic Enzyme S-7FE-1. J Chin Ins Food Sci Tech 10:013. Jurnal online http:// en.cnki.com.cn/Article_en/CJFDTOTA L-ZGSP201210013.htm diakses 12 Juli 2015 